Connecticut College

Digital Commons @ Connecticut College

History Faculty Publications

History Department

Summer 2014

\title{
The Absence of Context: Gay Politics without a Past
}

Jen Manion

Connecticut College,jmanion@conncoll.edu

Follow this and additional works at: https://digitalcommons.conncoll.edu/histfacpub

Part of the Lesbian, Gay, Bisexual, and Transgender Studies Commons

\section{Recommended Citation}

"The Absence of Context: Gay Politics without a Past," QED: A Journal in GLBTQ Worldmaking Vol. [1], Iss. [2], [year], pp. 115-31.

This Article is brought to you for free and open access by the History Department at Digital Commons @ Connecticut College. It has been accepted for inclusion in History Faculty Publications by an authorized administrator of Digital Commons @ Connecticut College. For more information, please contact bpancier@conncoll.edu.

The views expressed in this paper are solely those of the author. 


\section{The Absence of Context: Gay Politics without a Past}

Disciplines

Lesbian, Gay, Bisexual, and Transgender Studies

\section{Comments}

This Article originally appeared in QED: A Journal in GLBTQ Worldmaking Vol. [1], Iss. [2], [year], pp. 115-31.

Journal homepage: http://msupress.org/journals/qed/?id=50-214-F 


\title{
The Absence of Context: Gay Politics without a Past
}

\author{
Jen Manion
}

LGBTQ history is marginalized in so many ways. Its volumes are scarcely stocked in large warehouse bookstores - and certainly not in the actual history section that is dominated by books about war. Most U.S. history textbooks are deemed complete with a passing reference to Stonewall. Our own contemporary political movement for LGBTQ rights and equality has shown little interest in or need for knowledge of our community's history. Even feminist and queer academic spaces have taken an anti-historical turn; fields that count significant numbers of historians among their founders (such as women and gender studies or lesbian and gay studies) have become decidedly presentist. Just because the history of our communities, identities, and organizations is marginalized, however, does not diminish its significance.

The fact that Lady Gaga's "Born This Way" has become a gay anthem of sorts is not surprising. It affirms those who are being harassed by their families or religion to "change" their sexual orientation or gender identity. Those over the age of forty can enjoy pop culture's open embrace after decades of public gay-bashing disguised as political discourse. Although many (but by no means all) LGBTQ people believe they didn't "choose" to be gay, our simplistic celebration of this concept comes at a price. The idea of being "born this way" essentializes our often fraught and bumpy individual experiences of coming to terms with our sexual and/or gender identities while dehistoricizing queerness entirely. The concept actually eclipses the need for critical examination of gays as

Copyright (C) 2014 Michigan State University. Jen Manion, "The Absence of Context: Gay Politics without a Past," QED: A Journal in GLBTQ Worldmaking I.2 (20I4): II5-I3I. ISSN 2327-I574. All rights reserved. 
a group with a past. It was, however, a perfect anthem for the same-sex marriage campaign.

The 2008 passage of Proposition 8 triggered collective outrage and fueled the most widespread national protests for gay rights since record numbers of people took to the streets to protest the violent murder of Matthew Shepard in 1998. It may seem like ancient history in the wake of the 2013 U.S. Supreme Court ruling declaring the Defense of Marriage Act unconstitutional, but the backlash represented by the 2008 election-day passage of Proposition 8 overturning same-sex marriage rights in California motivated a new generation of activists to advocate for lesbian and gay equality and take to the streets. Immediately following this event, Join the Impact became the central organizing vehicle for nationwide protests. ${ }^{I}$ At a rally in New Haven, Connecticut, over 300 people gathered and marched. Nearly three dozen students from my campus, Connecticut College, woke up early that Saturday morning and drove to New Haven to join the nationwide effort. They brought handmade signs. One of them took over the microphone and inspired the crowd with a brief speech before leading the chant, "Yes to Love."

Young people spoke with passion and anger, moved by the conviction that fighting for the right of lesbians and gays to marry is, as one of them told me, "our generation's civil rights movement." The focus on same-sex marriage as the single most significant gay rights issue of our time and the shallow, polemical, and ahistorical debates that framed it, however, signal not how far we have come but rather how systemic and powerful heteronormativity really is.

This rally was a turning point for me as a queer feminist historian and activist who was ambivalent about the same-sex marriage movement, especially as it grew to overshadow other queer organizing. My involvement with student activists fired up about same-sex marriage forced me to face the fact that I was disappointed, annoyed, and a little lost. How could my community be consumed with something that I understood feminism and gay liberation to be against? In certain political and scholarly circles, there was a feeling of anguish over the fading potency of feminism in public discourse and the increasing conformity and depoliticization of the gay community.

The privileging of marriage has real consequences. It stigmatizes and threatens to further marginalize the most fabulous, polyamorous, free-loving, sex-loving, and gender-nonconforming segments of our community. ${ }^{2}$ Social stigma is one thing-legal stigma yet another. Legalizing same-sex marriage rather than working for legal rights to extend to a broader range of family, friends, and kin further reinforces discrimination against the unmarried. A 2004 survey by the U.S. General Accounting Office found I,I38 rights granted to married couples. ${ }^{3}$ Right 
now, marriage law perpetuates extensive institutional discrimination against the unmarried of all sexes, genders, and sexual orientations.

When I said I was against same-sex marriage, my students looked at me as if I had three heads. But I came to this after two decades of reading and thinking about the history of women's rights, gender roles, feminism, and patriarchy. Their total nonrecognition of my position required me to further understand and explain it myself. I am not technically opposed to same-sex couples being afforded the same legal and social recognition as opposite-sex couples, of course. But as Judith Butler writes, "Politics ... demands that we take a stand for or against same-sex marriage; but critical reflection, which is surely part of any seriously normative political philosophy and practice, demands that we ask why and how this has become the question." 4 And therein lay the source of my frustration - my inability to understand how and why marriage rights came to define my community. I turned to important scholarship by historians and queer studies scholars to help unpack this narrative, including work on homonormativity and homonationalism as well as John D'Emilio's powerful exposé of the consequences of the marriage campaign's numerous defeats. ${ }^{5}$

Most conversations about same-sex marriage in the national media completely skip over this point: How and why have marriage rights become the question of lesbian and gay equality? Another way to answer this is to look back to the history of the queer civil rights movement of the past fifty years. ${ }^{6}$ Rachel Maddow is one of the few national figures to pursue this line of inquiry. ${ }^{7}$ Before interviewing the famous cocounselors Ted Oslon and David Boies representing the plaintiffs in the California case, Maddow provided just this context for her viewers, noting that within the gay community in the I990s, same-sex marriage was actually seen as the most conservative direction for the movement to go. ${ }^{8}$ Just this small nugget of history provided invaluable historical and political context as an interesting lead-in to her story about the trial. Many of us who identified with the more progressive feminist wing of the movement are still surprised by this conservative turn. An increasingly marginalized group of scholars and activists within the LGBTQ community stand against the same-sex marriage agenda for both ideological and practical reasons, including feminist or Marxist critiques of the government regulation of private life and the belief that our activist money and energy would be better spent addressing the needs of the most marginalized members of our community: transgender people, young people, the elderly, and those suffering from race and class oppression. Community engagement and media coverage of the same-sex marriage campaign has left little room for these perspectives, though this is beginning to shift since the overturn of DOMA in 2013. ${ }^{9}$ 
Historians of the modern queer movement will one day mark the rise of the marriage campaign as a pivotal turning point for our communities whose consequences we cannot yet foresee. But the movement for same-sex marriage rights was not inevitable. Marriage is but one proposed solution to a particular set of indignities, many of which will persist for LGBTQ couples and individuals even if same-sex marriage is legalized in every state. History proves wrong the essentialist arguments that define marriage as a "timeless" institution necessitated by reproduction, religion, and biological determinism. Highlighting the history of the institution of marriage to provide historical perspective on the current national debate is one important piece of the puzzle. This can be seen in work by Nancy Cott, Peggy Pascoe, Stephanie Coontz, and George Chauncey, among others. As historians, however, we must connect the history of marriage to larger social movements.

This contemporary neglect of LGBTQ movement history is neither our legacy nor our destiny. Some of the most provocative and visible grassroots efforts have claimed movement predecessors as their inspiration—and justification. Consider the manifesto written by Queer Nation in 1990 in response to the conservatism of national (and LGBTQ) politics. As Simon Hall has argued, Queer Nation laid claim to the legacy of one of the movement's early organizationsthe New York Gay Liberation Front, which openly challenged racism, sexism, and imperialism. The Queer Nation manifesto stated, "Being queer is not about a right to privacy; it is about the freedom to be public, to just be who we are. It means everyday fighting oppression; homophobia, racism, misogyny, the bigotry of religious hypocrites and our own self-hatred."' The inability of an assimilationist strategy to bring about real structural change to American society was obvious to both groups. But historical precedent could as likely inspire conservative approaches to activism as well. Think of the early public protests by the East Coast Homophile Organizations outside of Independence Hall in Philadelphia, known as the "Annual Reminder." Marchers dressed in their gender-conforming Sunday best in orderly and quiet procession to appeal to respectability, hoping to impress passersby with the idea that lesbians and gay men were regular, nonthreatening, and just like everyone else. The tension between radical intersectional organizing and conservative single-issue strategies are deeply wound into the core of the movement's history. ${ }^{\text {II }}$

The absence of knowledge about this history has shaped a very presentist and centrist analysis of the same-sex marriage movement. In organizing rallies, collecting signatures, raising money, and recruiting supporters, the idea of stopping to read some history books and discuss the long-ago past might seem absurd. And yet time and again, in conversation with experienced activists and 
young people alike, I couldn't help but think how much knowledge of the past would enrich their organizing, coalition building, decision-making, and strategic thinking in the present. Our community desperately needed to be more engaged with our histories_ and historians.

In January 20I0, the newly invigorated same-sex marriage movement made history when it collided with the largest organization of professional historians. ${ }^{12}$ The American Historical Association's annual meeting was held in the Manchester Grand Hyatt, a hotel that was being boycotted by the LGBTQ and labor communities in San Diego for its owner's role in financing the movement for Proposition 8 in addition to a number of workers-rights issues. A wide range of groups were behind the boycott including The San Diego LGBT Center, San Diego Equality Campaign, Californians Against Hate, San Diego Alliance for Marriage Equality, Marriage Equality USA-San Diego, Sleep With the Right People-Southern California, Equality California, Courage Campaign, UNITE HERE International Union, and the San Diego County Labor Council. These groups were committed to enforcing the boycott, which included not staying in the hotel, patronizing the businesses inside, or even entering the building. The groups occasionally organized rallies outside and hosted one on Saturday afternoon during the AHA annual meeting, drawing the participation of a few dozen historians. ${ }^{13}$

The AHA determined it would lose nearly $\$ 800,000$ (a \$6II,000 cancellation fee and $\$ 180,000$ in lost negotiated concessions $)^{I 4}$ and potentially bankrupt the organization if it relocated. The AHA decided to host a mini-conference within the conference on same-sex marriage to show it took the issue of discrimination against LGBTQ people seriously and would make space for people to engage scholarship on related topics. ${ }^{15}$ Still, the decision to keep the conference in a hotel owned by a prominent funder of anti-gay initiatives was devastating for many LGBTQ historians, particularly those from California who lived through the vicious campaign. Craig Lofton described the political climate in California leading up to the Prop 8 vote, "It was a perpetual gay-bashing that lasted for months, amplified by the media and bolstered by state authorities." Hundreds of anti-gay signs were illegally posted on public property near his home in Long Beach. Law enforcement and local government officials refused to have them removed, despite their violation of election laws. Lofton wrote about the blitz of hatred, "This is in addition to the hateful, vicious, mean-spirited, bigoted lies about gay people being run constantly on TV ads and in quotes everyday in our newspaper." For Lofton and others, the criticism embedded in the campaign over same-sex marriage rights in California was both violent and personal; the AHA's compromise plan-to issue statements disapproving of Manchester's 
bigotry while conducting business as usual-was not enough. Lofton wrote, "And now, despite the panels and pretense of happy resolution by the AHA ... thousands of AHA members will be staying at that hotel, buying coffee and muffins and bagels, buying their newspapers, etc. I cannot accept this. The wounds from Prop 8 heal slowly. The AHA's compromise is pragmatic but morally unacceptable to me." ${ }^{16}$ Many powerful and important voices of activists and academics from near and far were absent from the panels and conversations that weekend because they chose to stand with integrity and conviction for the principal of justice and equality.

Those of us in attendance were torn between our professional interests and responsibilities, the desire to put our political convictions into practice, and the personal compulsion to stand up for our own dignity as queer people, the targets of hatred and bigotry. Some historians attended the conference but stood in solidarity with the boycott, refusing to enter the Hyatt under any circumstances, even for panels, registration, business meetings, or the book exhibit. This was the position adopted by then chair of the Committee on LGBT History, Ian Lekus. Although admiring the decision and conviction of both Ian and Craig, I chose to attend and participate for two reasons: First, local activists were not clear or constructive in communicating with us in the year leading up to the meeting. A number of LGBTQ historians reached out to Cleve Jones, one of the chief organizers, far in advance to discuss strategy. Marc Stein, member of the Task Force on LGBTQ Historians, was one of several who received no response. Stein later said, "Here there was a group of queer historians who wanted to ally with queer labor to figure out how to deal with the situation, and our efforts were just ignored until it was too late, pragmatically, to push for alternatives. And then we were denounced publicly. I lost respect for Cleve Jones in that context." ${ }^{17}$ I was not comfortable pulling out in protest when the details of the local developments and the terms of the boycott were so unclear. Second, as a board member of the Committee on LGBT History at the time, I felt compelled to be present and help navigate the potential conflicts between local LGBTQ activists (my people) and professional historians in attendance (my colleagues). The Governing Board of Committee on LGBT History worked hard in the months prior to draft a position statement for the meeting that we circulated to our membership as well as to the leadership of the AHA. Queer historians were largely left in the dark about the plans of local queer organizers while the AHA leadership made some questionable decisions and ignored the best advice of both the Committee on LGBT History and the LGBTQ Historians Task Force. ${ }^{18}$

The AHA decided to address the boycott of the Manchester Hyatt by creating a special mini-conference within the annual meeting on the history of same-sex 
marriage. This perspective served to highlight the different ways that marriage laws have been used throughout history to sanctify some partnerships and delegitimize others. Some historians complained that the mini-conference on same-sex marriage was evidence of pandering to the gay agenda and giving gay history "special" consideration. But our treatment as LGBTQ historians was "special" for all the wrong reasons. The AHA mishandled the mini-conference in many ways. They denied our request that the mini-conference sessions be moved out of the Hyatt so no one would have to violate the boycott to attend. This put the entire set of special sessions out of reach of those who might most benefit from the knowledge- local activists fighting the discriminatory law and principled LGBTQ historians. The plaintiffs in Perry v. Schwarzenager, challenging the constitutionality of Proposition 8 in federal court, knew that history was a great weapon and called several historians of marriage to testify to the institution's dynamic and changing dimensions. This great opportunity for creating a powerful conference was lost.

The AHA ignored the organizing efforts of Committee on LGBT History, which issued an informative and thoughtful press release about the situation months in advance to help inform attendees of the situation. The AHA did not pass on our information, nor did they communicate in advance with meeting registrants about the boycott or options available for changing their room reservations. If you were not actively engaged in gay political activism, you might have no idea there was a boycott or a controversy. Even worse, at a late hour, the AHA sent an official communication out ONLY to those who were presenting on panels in the mini-conference, as if they were the only people who need be bothered. But worst of all, they employed a bizarre authoritarian approach to information and security at the conference itself. First, they had multiple guards stationed in the rooms during mini-conference sessions. This was terrifying and baffling. I have never felt so unsafe or nervous at an academic conference. I wondered who decided this was the price we had to pay for sharing the history of our community. I wondered who they were trying to protect from whom. Was I to be protected or constrained? There were no answers, just guards and "talking point" fact sheets for chairs to defend the organization against the potential protesters who never materialized. Why? Because they were boycotting the hotel!!!! All the security measures did was remind me how hostile the profession has been to the field of LGBTQ history—and by extension, our communities and lives.

One of the reasons that most people know very little about gay history is that the historical profession has been very slow to recognize LGBTQ history as important, relevant, or even legitimate. The groundbreaking collection of doc- 
uments in Gay American History: Lesbians and Gay Men in the U.S.A. (1978) was compiled by a self-taught researcher, Jonathan Ned Katz. John D'Emilio's Sexual Politics Sexual Communities: The Making of a Homosexual Minority in the United States, 1940-1970 (1983) was a rare monograph penned by a professional historian and published before 1990. Another founding father of the field, Martin Duberman, coedited (with Martha Vicinus and George Chauncey) the seminal Hidden from History: Reclaiming the Gay and Lesbian Past in 1990. His monograph Stonewall followed in 1993. The historical profession itself was explicitly hostile to serious analysis of lesbian and gay history for so long that many of the earliest works in the field were published by journalists and scholars trained in other fields, chiefly literary criticism and anthropology. Odd Girls and Twilight Lovers: A History of Lesbian Life in Twentieth-Century America by Lillian Faderman; Making History: The Struggle for Gay and Lesbian Equal Rights, 1945-1990: An Oral History by Eric Marcus; Boots of Leather, Slippers of Gold: The History of a Lesbian Community by Madeline Davis and Elizabeth Kennedy; and Esther Newton's Cherry Grove, Fire Island: Sixty Years in America's First Gay and Lesbian Town are a few examples. ${ }^{19}$

The LGBTQ community has created many of our own archives, recognizing that if we did not preserve the documents, lives, and histories of ourselves, that no one would. Major collections can be found in San Francisco, Los Angeles, Chicago, Philadelphia, and New York, but dozens of other cities, including San Diego, have rich and diverse holdings as well. The Lesbian Herstory Archives was born out of a lesbian-feminist consciousness-raising group in 1974 and made its home in the apartment of Joan Nestle for nearly twenty years. The statement of purpose reflects the distrust they felt towards "patriarchal historians" who controlled the past: "The Lesbian Herstory Archives exists to gather and preserve records of Lesbian lives and activities so that future generations will have ready access to materials relevant to their lives. The process of gathering this material will uncover and collect our herstory denied to us previously by patriarchal historians in the interests of the culture which they serve." 20 The ongoing commitment to alphabetizing their library books by first name rather than surname is a statement against patriarchal naming practices and reflects feminist values popular in the rig7os.

Community history projects have popped up across the country as well. The Boston History Project was established in 1980 and notes the challenges of preserving community history in its mission statement, "Since the documentation of the gay and lesbian experience is fragmentary and scattered, it has remained largely inaccessible to researchers, educators, the general public, and even the gay community itself. Through its mission, BHP seeks to provide an 
accurate portrayal of the contributions our community has made to the political, cultural and economic life of the region." ${ }^{21}$ The GLBT Historical Society of San Francisco was founded in 1980 and sponsors the GLBT History Museum, the "first full-scale, stand-alone museum of its kind" in the United States. ${ }^{22}$ My own love of history was stoked in the I990s in the one-room library/archives of the Philadelphia gay community center then known as Penguin Place and run by volunteer Steven Capsuto, now greatly expanded and named the John J. Wilcox, Jr. LGBT Archives in the William Way LGBT Community Center. ${ }^{23}$

In the past twenty years, an increasing number of queer scholar/activists have been trained as professional historians and are documenting our past. The explosion of original monographs in LGBTQ history has coincided with the increasing acceptance of LGBTQ studies as a legitimate field of scholarly engagement and widespread student interest in sexuality studies. Some of these works include John Howard's Men Like That, Marc Stein's City of Sisterly and Brotherly Loves, Karen Krahulik's Provincetown, Nan Boyd's Wide Open Town, Marcia Gallo's Different Daughters, David Johnson's The Lavender Scare, and Martin Meeker's Contacts Desired. More recent books include Transgender History by Susan Stryker, Bohemian L.A. by Daniel Hurewitz, Pre-Gay L.A. by C. Todd White, Infectious Ideas by Jennifer Brier, Not in this Family by Heather Murray, and Radical Relations by Daniel Winunwe Rivers. ${ }^{24}$ This list does not include the many books more properly categorized as histories of sexuality rather than LGBTQ community studies.

This surge in publications has resulted in the creation of a "usable past"-a body of work in LGBTQ movement history, which is not, as some people say, a narrow subspecialty within twentieth-century U.S. political history. Rather, histories of the LGBTQ movement and our communities more generally provide EXACTLY the kind depth and breadth of information one needs to develop a nuanced understanding of one of the most hotly debated social and legal issues of our day-the role and status of LGBTQ people in American society. Historians have several important contributions to make to these contemporary debatesand people have much to learn from the study of LGBTQ history. Young people understand this. Years ago, I offered the first course in my history department explicitly on LGBTQ history and it filled to capacity overnight. On our small campus, no more than a handful of students in the course openly identified as members of the LGBTQ community. Puzzled by student interest in the subject, over the course of the semester it became clear to me: For the past twenty years-longer than some of them have been alive- the rights of LGBTQ people to live and work and love have been hotly contested in the national, state, and local political arenas. They want to know why. It is our job to teach them. 
The anti-gay right in this country has made it a common practice to reframe calls for an end to discrimination against LGBTQ people as a demand for "special rights" and aims to cultivate fear in others about how special rights for the gays will result in some kind of loss for themselves. Although evidence of the discrimination, intimidation, and isolation faced by LGBTQ people in this country has been widely documented and is readily available in any number of media or scholarly sources for anyone to access, the rhetoric of "special rights" carries a great deal of weight in the popular imagination. In fact, LGBTQ history is one of the most marginalized specialties in the profession. Marc Stein, former chair of CLGBTH, documented this professional marginalization extensively in his 200I report, which was published in Perspectives and can be accessed at the AHA Website. ${ }^{25}$

Historians are a diverse and motley crew. Although the AHA's Official Statement on Standards of Professional Conduct advocates a nondiscrimination policy that includes sexual orientation, this by no means signifies that all or even most historians support same-sex marriage or even LGBTQ civil rights more generally. ${ }^{26}$ Intellectual freedom in deciding what to teach in our courses is something both prized and hotly contested in the profession. Each semester, as we build our courses, we face the challenge of deciding what topics and texts are so important that we must include them. We debate with ourselves and our colleagues about the value in assigning "classic" and "seminal" works of history verses the newest and most cutting edge studies that may not stand the test of time. We struggle with defining what the "narrative" of our course will be-and which arguments and ideas we will use to disrupt it.

This is one of the places where LGBTQ history gets lost. LGBTQ historyeven for historians who are generally supportive of LGBTQ civil rightsbecomes a "special" issue and if they make time or space for the "special" issue, some other beloved book or article or topic will be lost. Others might read LGBTQ history on their own but can't justify dedicating an entire week of their syllabus to the study of a group of people that is so small—so marginal to history. Still others worry about the reception of students, the gaze of department chairs or tenure committees. These examples may capture only a few of the reasons why historians neglect to teach LGBTQ history in their courses. My main point here is to reframe this dynamic, just as gay activists continually reframe the narrative of "special" rights to highlight the reality of our discrimination. Occasional recognition of a book, such as that enjoyed by George Chauncey's seminal work Gay New York, which was widely assigned in graduate seminars for years, signals tokenism and has not resulted in widespread reconceptualization of the period. ${ }^{27}$

Any textbook or survey course in U.S. political, urban, women's, or general history that neglects the LGBTQ community is presenting historical fiction. In 
the newest edition of a widely taught thousand-page U.S. history textbook, I found that gay life and community was covered in less than one page. One paragraph covered the early part of the twentieth century and one paragraph covered the modern gay rights movement. This minimal inclusion is progressand for many young people, the only introduction to LGBTQ history they will ever have. Historian Vickie Eaklor did an exhaustive study of the representation of LGBTQ history in U.S. history textbooks aimed at the college market. Although in 1991, she found only two of twenty-three books had more than one short paragraph on the subject, this dramatically improved in 2004. When Eaklor redid this study, eleven of twenty-seven volumes earned an "A/A-“ in her evaluation system, which meant "more detail on basics and/or more than I960s-90s and/or more than two columns/one page." ${ }^{28}$ Although coverage of gay men increased, chiefly through introduction of discussion about AIDS, representation of lesbians and transgender people was negligible. It should clear, however, that Eaklor set the bar rather low for these studies. One could easily make the case that five-percent of each volume be dedicated to LGBTQ issues, based on a conservative estimate of our proportion of the population. By this barometer, fifty pages of a one thousand-page textbook would reasonably cover our lives. This absence is a pervasive and blatant form of systemic discrimination. But there is hope-and movement. A new U.S. history survey textbook, Exploring American Histories by Nancy Hewitt and Steve Lawson, contains a remarkable amount coverage including twelve distinct aspects of our history, though still nowhere near five-percent of the volume. ${ }^{29}$

Widespread ignorance about the history and diversity of LGBTQ people and communities still stands as a significant obstacle in the movement for freedom and equality. The popular and timely historical website, History News Network, uses the tag line, "Because the Past, is the Present, and the Future too." We know all too well that the denial and silencing of our past serves to marginalize and oppress us in the present. Although anti-gay right wing forces may actively work to deny the availability of such information, even those who support and defend the dignity of gay people, even liberals, and even our allies fall prey to this insidious form of homophobia. Former Committee on LGBT History chair Karen Krahulik recently noted how otherwise educated and informed people know little about LGBTQ history. "It is unheard of," she remarked, "for an issue to be so hotly contested in American politics without a corresponding rush to learn about its history." 30 This marginalization of LGBTQ history within the historical profession, however, is out of step with student interest in the subject. Many of us teaching courses in the history of sexuality or LGBTQ history report them being filled year after year, at both the graduate and undergraduate level. 
We must continue to teach these courses regularly and work to make them mainstays of history department curriculum in schools large and small.

The erasure of LGBTQ experience from most of history, the resistance of teachers and professors to teaching our history, and the widespread belief that the histories of our lives and communities are minor, marginal, and irrelevant to the story of U.S. history are blatant acts of hostility and oppression. As instructors of U.S. history at diverse institutions across the country and even around the world, we are poised to change that. When I was an undergraduate history major, I looked to social justice movements of the past to better understand the culture wars of the I990s. Historical studies about the women's movements and the African-American civil rights movement were readily available and provided me with a much deeper understanding of the issues, positions, and people involved in national debates over welfare, abortion, prisons, and immigration. It inspired in me a love of the past, not as a static record of events but as a living documentation of experiences and struggles which continued to shape peoples' lives_-including my own-in the present.

The fight for same-sex marriage rights rages on, though less urgently for those of us living in states where it has been legalized. Standing with hundreds of mostly young people in New Haven that day did not assuage my own ambivalence about same-sex marriage. Although inspired by their enthusiasm and conviction, I wondered why they weren't as passionate about fighting for transgender rights, employment nondiscrimination laws, or against the physical and rhetorical violence so many of us face every day. I couldn't help but wonder what they would think of the marriage movement if they studied the activism of Mattachine Society or Daughters of Bilitis; if they studied the sexual revolution that gave rise to both women's and gay liberation.

I wonder if Barney Frank and the legions of gay assistants, activists, and lobbyists who decided to exclude transgender people from Employment NonDiscrimination Act would have made the same decision if they really studied the history of the Stonewall Riots or watched Susan Stryker's path-breaking documentary, Screaming Queens: The Riot at Comptons Cafeteria. I wish our community really reflected on the major role transgender and working-class people played in some of our movement's most important moments. I wonder if the editors of the Advocate who ran the cover story "Gay is the New Black" might have thought differently if they read about the vibrant African-American communities featured in George Chauncey's Gay New York. These are just a few examples of how knowledge of the past might inform a more thoughtful, inclusive, and even radical present. Thankfully, it's not too late to do something. 
Academics and activists alike can do much to challenge widespread ignorance of the LGBTQ past. For those teaching college right now, it is very easy. Knowledge is power. Teaching LGBTQ history in your classes does not make you a gay activist. Recognizing LGBTQ history as central to the narrative of U.S. history rather than marginal, incorporating it into courses in a thoughtful way, committing yourself to reading at least one new LGBTQ history monograph each year, supporting junior colleagues who teach LGBTQ content, and taking job candidates with LGBTQ themed dissertations seriously as general scholars are all powerful steps you can take to stand against the longstanding marginalization and suppression of the gay past. High-school and middle-school teachers generally have greater constraints than college faculty but have much to offer if they can incorporate LGBTQ history into their courses and class projects. Our students are ready. So start now, insuring that future generations will have the information they need to make sense of struggles of their times.

LGBTQ history is an easy way to do important work that engages students, scholars, and activists. On my campus, I coordinated a "Know Your Hirstory" campaign. Given the use of "hir" as a gender neutral pronoun in the transgender community, the "hirstory" campaign is meant to be decidedly trans inclusive while also spinning off of traditional "history" and lesbian/feminist calls for "herstory." We called it "a gender inclusive study of the past." The first project of this campaign was done in conjunction with the college library and involved two components: a display of favorite LGBTQ themed books by faculty, staff, and student leaders on campus along with profiles of those people and a list of their recommendations. ${ }^{3 \mathrm{I}}$ The second component was a banner and bookmark meant to draw attention to the campaign and give people something to take away with them. Working with a student design team, we came up with graphics that used a black background, white lettering, and pink triangles to teach about the history of Nazi persecution of gays during the Holocaust as well as how ACT UP appropriated the symbol for their activism. The campaign worked—students, faculty, and staff are hungry for more.

As with the first generation of LGBTQ historians, the activist community is not sitting around waiting for academics to create a usable past. The internet, digital technologies, and social media have all made this easier as artists, writers, activists, archivists, public intellectuals, and historians have created a virtual explosion of queer history in the recent past. A notable but not exhaustive list of these projects includes: The ACT UP Oral History Project, which offers video text of interviews with members of ACT UP New York, who were on the front lines in the fight against widespread public and government indifference to the HIV/AIDS crisis. Gay history pioneer Jonathan Ned Katz founded OUT history to be the "go to" place for queer 
history online. ${ }^{32}$ The Pop-Up Museum of Queer History has taken the creative queer community by storm in expanding the notion of historical subjects and representations. ${ }^{33}$ The Queer Newark Oral History Project is community based and directed. ${ }^{34}$ These projects are just the tip of the iceberg.

More and more mainstream museums, libraries, and archives are curating exhibits in LGBTQ history as well. Two examples on opposite sides of the country had their opening nights on Valentine's Day, February I4, 20I4. The Museum of History and Industry in Seattle, Washington, hosted an exhibit called "Revealing Queer" to explore how the community has "grown, changed, become more visible, and worked toward equality" in the Puget Sound region. ${ }^{35}$ The Library Company of Philadelphia-America's first lending library, which was founded by Benjamin Franklin — curated an exhibit from its vast collection called "That's So Gay: Outing Early America" and features an online component as well. ${ }^{36}$

History can also seem like a safe way for others to learn about our community. My own current research project on transgender histories of the eighteenth and nineteenth centuries is an accessible way for people to think critically about the gender binary, crossing, passing, binding, language, and pronouns. It engages a number of issues pressing to the transgender community today and allows people to learn about these issues without burdening individual transgender people with their questions. ${ }^{37}$ Just because learning this way seems safe to those new to our communities does not make its impact any less powerful.

The widespread ignorance about the history and diversity of LGBTQ people stands as the single most significant obstacle to our liberation, justice, and equality. Although anti-gay right wing forces actively work to suppress such information, even those who support and defend the dignity of LGBTQ people (even liberals) fall prey to this insidious form of homophobia and transphobia. LGBTQ history is one powerful tool to use as we try to shift the terms of public discourse, incorporating lessons from the past so we may move beyond our historic limitations in imagining a queer future worth living.

\section{NOTES}

I. Join the Impact describes itself as a "grassroots and netroots" organization. See http://jointheimpact.com/.

2. Lisa Duggan develops this argument and coined the term "homonormativity" in The Twilight of Equality: Neoliberalism, Cultural Politics, and the Attack on Democracy (Boston: Beacon Press, 2003).

3. http://www.marriageequality.org/I-I38-federal-rights.

4. Judith Butler, "Is Kinship Always Already Heterosexual," differences: A Journal of Feminist Cultural Studies I3, no. I (2002): I4-44. 
5. Duggan, Twilight of Equality; The Radical History Review, "Queer Futures," 2008, no. IOO, (Winter 2008); Jasbir Puar, Terrorist Assemblages: Homonationalism in Queer Times (Durham, NC: Duke University Press, 2007); Judith Butler, Undoing Gender (New York: Routledge, 2004); John D’Emilio, “The Marriage Fight is Setting us Back," The Gay and Lesbian Review, vol I3: 6 (November-December, 2006): IO-II.

6. For reflection on these questions, also see John D'Emilio, The World Turned: Essays on Gay History, Politics, and Culture (Durham, NC: Duke University Press, 2002).

7. Rachel Maddow Show, MSNBC, January I2, 20IO, http://vodpod.com/watch/ 2854568-rachel-maddow-interviews-prop-8-attorneys-ted-olson-and-david-boies.

8. For more on this debate within the movement see Urvashi Vaid, Virtual Equality: The Mainstreaming of Gay and Lesbian Liberation (New York: Anchor, 1995); Andrew Sullivan, Virtually Normal: An Argument about Homosexuality (New York: Knopf, 1995).

9. For example, The New York Times ran an article in "Sunday Styles" featuring longterm gay couples who were not married called "Gay Couples Choosing to Say 'I Don't." See http://www.nytimes.com/20I3/Io/27/style/gay-couples-choosing-tosay-i-dont.html?pagewanted $=$ all\&_r $=0$.

Io. Queer Nation Manifesto in Simon Hall, "Americanism, Unamericanism, and the Gay Rights Movement," Journal of American Studies 47, no. 4 (2013): II5. Also see Marc Stein, Rethinking the Gay and Lesbian Movement (New York: Routledge, 20I2).

II. Stein, City of Sisterly and Brotherly Love.

I2. Protestors, led by Cleve Jones, carried a clever sign that read, "What will history say about American Historical Association?" For images of sign, see http:// wockner.blogspot.com/2010/oI/300-march-on-hyatt-as-history.html.

I3. For a report on the rally, see Inside Higher Ed, http:/www.insidehighered.com/ news/20Io/oi/ri/rally. For video, see History News Network, http:/hnn.us/ roundup/entries/I22O2I.html.

I4. Email communication between AHA Executive Director Arnita Jones and members registered to participate in the mini-conference sessions, "AHA and the Manchester Hyatt," November 17, 2009. This information was also available in print at the conference itself.

15. I wrote a brief account of this controversial event as a guest blog for Tenured Radical, January I9, 20I0. See http://chronicle.com/blognetwork/tenuredradical/ 20Io/or/guest-post-aha-blew-it/.

16. Email communication with Committee on LGBT History members by Craig Lofton, received January I2, 2010.

17. Email correspondence with Marc Stein, March 2013. Other members of the Task Force on LGBTQ Historians at the time included Leisa Meyer (chair), Susan Stryker, Jennie Brier, and David Weber, vice president of the Professional Division of the AHA. The AHA Council approved this group's formation in 2009. This is distinct from the Committee on LGBTQ History, an independent, affiliated society of the AHA. See https://www.historians.org/about-aha-and-membership/aha-history-and-archives/ annual-reports/annual-report-2009/professional-division-2009. 
I8. For full text of this letter dated November 2009, see http://clgbthistory.org/ pressrelease.html.

19. Jonathan Ned Katz, Gay American History: Lesbians and Gay Men in the U.S.A. (New York: Crowell, 1976); John D’Emilio, Sexual Politics Sexual Communities: The Making of a Homosexual Minority in the United States, 1940-1970 (Chicago: University of Chicago, 1983); Martin Duberman, Martha Vicinus, and George Chauncey, Hidden from History: Reclaiming the Gay and Lesbian Past (New York: NAL Books, 1989); Martin Duberman, Stonewall (New York: Dutton, 1993); Lillian Faderman, Odd Girls and Twilight Lovers: A History of Lesbian Life in Twentieth-Century America (New York: Columbia University Press, I991); Eric Marcus, Making History: The Struggle for Gay and Lesbian Equal Rights, 19451990: An Oral History (New York: HarperCollins, 1992); Madeline Davis and Elizabeth Kennedy, Boots of Leather, Slippers of Gold: The History of a Lesbian Community (New York: Routledge, 1993); Esther Newton, Cherry Grove, Fire Island: Sixty Years in America's First Gay and Lesbian Town (Boston: Beacon, 1993).

20. Lesbian Herstory Archives, http://www.lesbianherstoryarchives.org/history.html.

2I. The History Project, Boston, http://www.historyproject.org/about/about.php.

22. GLBT History Museum, San Francisco, http://www.glbthistory.org/museum/index.html.

23. See http://www.waygay.org/index.php/site/view/9I.

24. John Howard, Men Like That: A Southern Queer History (Chicago: University of Chicago Press, 200I); Marc Stein, City Of Sisterly And Brotherly Loves: Lesbian And Gay Philadelphia, 1945-1972 (Chicago: University of Chicago Press, 200o); Karen Krahulik, Provincetown (New York: New York University Press, 2005); Nan Boyd Wide Open Town: A History of Queer San Francisco to 1965 (Berkeley and Los Angeles: University of California Press, 2005); Marcia Gallo, Different Daughters: A History of the Daughters of Bilitis and the Rise of the Lesbian Rights Movement (Seal Press: Emeryville, CA, 2006); David Johnson, The Lavender Scare: The Cold War Persecution of Gays and Lesbians in the Federal Government (Chicago: University of Chicago Press, 2006); Martin Meeker, Contacts Desired: Gay and Lesbian Communications and Community, 1940s-1970 (Chicago: University of Chicago Press, 2006); Susan Stryker, Transgender History (San Francisco: Seal Press, 2008); Daniel Hurewitz, Bohemian L.A. and the Making of Modern Politics (Berkeley and Los Angeles: University of California Press, 2008); C. Todd White, Pre-Gay L.A.: A Social History of the Movement for Homosexual Rights (Urbana: University of Illinois Press, 2009); Jennifer Brier, Infectious Ideas (Chapel Hill: University of North Carolina Press, 20Io); Heather Murray, Not in this Family (Philadelphia: University of Pennsylvania Press, 20II); Daniel Winunwe Rivers, Radical Relations (Chapel Hill: University of North Carolina Press, 2013).

25. For full text of "Committee on Lesbian and Gay History Survey on LGBTQ History Careers” by Marc Stein, see http://www.historians.org/perspectives/issues/ 200I/oios/orosaffr.cfm. 
26. The Official Statement on Standards of Professional Conduct can be found online at http://www.historians.org/pubs/free/professionalstandards.cfm.

27. George Chauncey, Gay New York: Gender, Urban Culture, and the Making of the Gay Male World, 1890-1940 (New York: Basic, 1995).

28. Vicki L. Eaklor, "How Queer-Friendly Are U.S. History Textbooks?" January 2004, clgbthistory.org/resources/reports.

29. Relevant topics indexed include: Daughters of Bilitis; Gay liberation, Rustin on; Gays \& Lesbians: activism of, ACT UP protest, in the late nineteenth century, in military; Homosexuals and homosexuality: in 1950s, communism and, gay and lesbian activism, in military, Nazis, Rustin, same-sex marriage, social conservatives; Alfred Kinsey; Lesbians: in I950s, women's movement; Stonewall Tavern, riot; Healthcare-AIDS; Mattachine Society; Nancy Hewitt and Steven Lawson, Exploring American Histories (Boston: Bedford St. Martin, 2013).

30. Conversation with former Committee on LGBT History chair Karen Krahulik, 20 Io.

3r. Longtime librarian and great queer ally Ashley Hanson did most of the work for this.

32. Out History, http://www.outhistory.org.

33. Pop-up Museum of Queer History, http://www.queermuseum.com.

34. Queer Newark Oral History Project, http://queer.newark.rutgers.edu.

35. "Revealing Queer" Exhibit, Museum of History and Industry, Seattle, WA, www.mohai.org/exhibits/item/2620-revealing-queer.

36. "That's So Gay: Outing Early America" Exhibit curated by Connie King, Chief of Reference at the Library Company of Philadelphia. Digital version at: http:// www.gayatlcp.org/blog.

37. This project is tentatively titled, "American Transgender Histories: from Revolution to Civil War." Some primary sources from this research can be seen at crossinggender.tumblr.com.

Jen Manion is Associate Professor of History and American Studies and Director of the LGBTQ Resource Center at Connecticut College. Manion received a BA in history from the University of Pennsylvania and a $\mathrm{PhD}$ in history from Rutgers University. Manion works at the intersection of activism and academia, believing both spheres of activity and inquiry have much to offer the other. Their publications include Taking Back the Academy: History of Activism, History as Activism (Routledge, 2004) and numerous essays and reviews. Jen's book Liberty's Prisoners: Gender, Sexuality, and Punishment in Early America is forthcoming from University of Pennsylvania Press. Jen is thrilled to have contributed to the first volume of the new journal TSQ: Transgender Studies Quarterly with an entry titled "Transbutch." For more info, see JenManion.tumblr.com. 